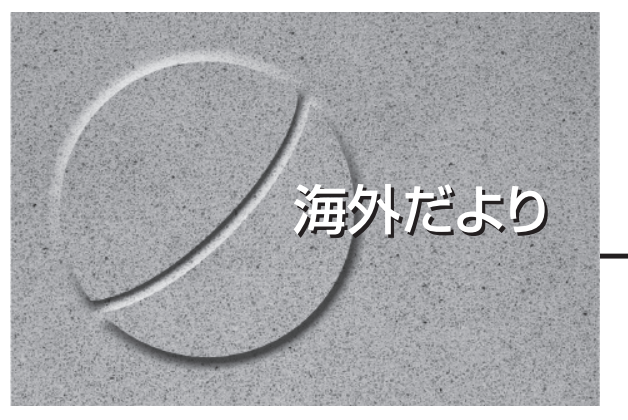

\title{
IFSTTAR
}

\section{川端 雄一郎*}

はじめに

筆者は, 2014 年 9 月から, フランスの IFSTTAR (Institut français des sciences et technologies des transports, de l'aménagement et des réseaux) に滞在 している。IFSTTAR は LCPC（フランス土木研究所） と INRETS（国立交通安全研究所）が 2011 年に統合し た研究機関であり，LCPC と聞けば馴染みのある読者の 方も多いかもしれない。本稿では，IFSTTARの概要と 研究，フランスでの生活について紹介する。

\section{IFSTTAR}

IFSTTAR は LCPC 時代にはパリに研究所を置いてい たが，統合に伴って Marne-la-Vallée に拠点を移した (写真-1)。研究所の本部はパリ市内から RER A 線 1 本 で約 20 分と, 比較的容易にアクセスできる。その他, ナントやマルセイユ,リヨンなどにも研究拠点がある。 約 1200 名の研究者が在籍しており, そのうち約 240 名 は博士課程の学生である。研究部は 5 部門に分類され, その部門の中でさらに数研究室に分けられている。筆 者は構造材料部門の研究室（SDOA）に在籍している (写真-2)。研究室には博士課程の学生も含めて 14 名在 籍して抢り, 劣化が生じた構造物の性能評価, SHM な どを活用した構造物のマネジメント, 構造物の脆弱性・ 堅牢性とリスク評価・管理，などが主な研究対象となっ ている。

IFSTTAR は前述の通りLCPC と INRETS が統合し た研究機関であるが,パリ東大学の一部でもある。同僚 に聞いたところによれば，これにはフランス独自の事情 があるとのことであった。世界大学ランキングを見ると， フランスの大学は上位に現れない。この理由の一つとし て，フランスのグランゼコールという専門性の高い高等教 育機関の存在がある。グランゼコールは少数精鋭で高度 専門教育を行う，所謂エリート養成校である。土木系の グランゼコールではENPC (École Nationale des Ponts et Chaussées）が有名で，コンクリート分野ではフレシ ネー，流体分野ではナビエといった著名な技術者が卒業

* かわばた・ゆういちろう/国立研究開発法人港湾空港技術研究所 (正会員)

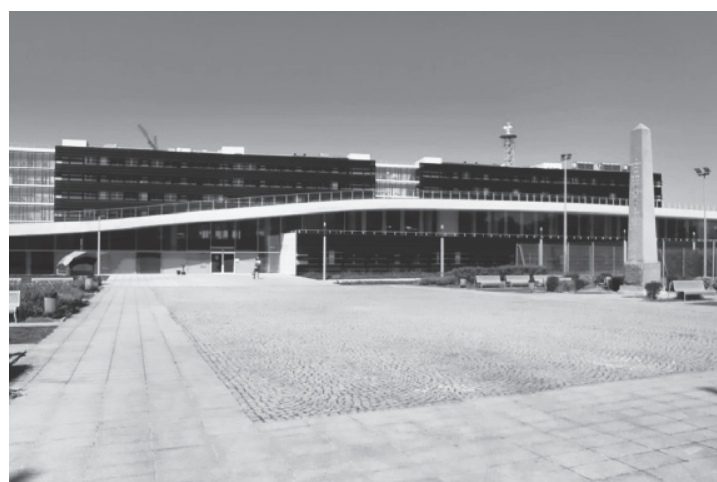

写真-1 IFSTTAR 外観

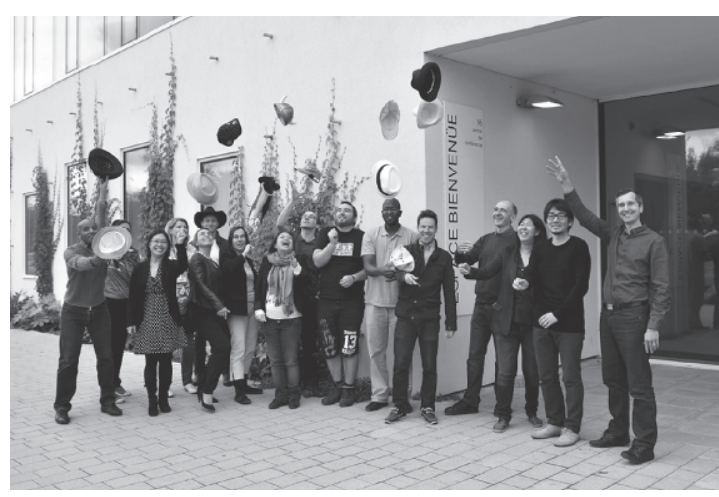

写真-2 研究室の集合写真

している。しかしながら，このような少数精鋭のグラン ゼコールは大学ランキング形式では評価されるのが難しい ようである。この対策として, 幾つかの教育機関・研究機 関がパリ東大学を形成し，一つの大学として競争するこ とを目指しているとのことである。ENPC はIFSTTAR の正面に位置しており，IFSTTARの研究者が講義をす ることもあり，密接な関係にある。また，ENPCの中に はNavier という独立した研究組織があり，IFSTTAR と ENPC, CNRS（仏国立科学研究センター）が共同出資 して本組織を運営している。組織体制が非常に複雑であ るが，内部での交流は盛んに行われている。

IFSTTAR は欧州でも土木系では最大規模の国立研究 所で，国内外の交流も盛んである。欧州を中心に様々な 方面の研究機関との交流がなされ，2 週に1 回程度で 様々な分野のワークショップが開かれている。筆者の IFSTTAR 着任日にはちょうど土木研究所との研究交流 
会が開催されており，日一仏の研究者間で積極的な議論 がなされていたのが印象的であった。

\section{ISR}

筆者は, 日本学術振興会の海外特別研究員として渡航 する機会を得て, 主にアルカリシリカ反応 (ASR) 遅延エ トリンガイト生成（DEF）といったコンクリートの内部 膨張反応 (ISR) に関する研究を行っている。これまで, 筆者は ISR に関する材料面の研究を主に行っていたが, IFSTTAR ではより構造面に着目して研究を行っている。

日本では現在でも ASR による劣化事例はわずかなが ら報告されているが，フランスでは ASR 抑制対策が講 じられた後に劣化事例は無いとのことである。一方で, 近年ではDEF によるマスコンクリートの劣化が顕在化 しており，100 以上の構造物が DEFによる劣化を生じ ているという。このためIFSTTARの近年の研究は DEF の検討が中心だったが，最近では ASR と DEF の 複合劣化などにも取り組んでおり, 数研究室共同で研究 が進められている。これらの成果を基に，新設時の予防 対策や既設構造物のマネジメント等がガイドライン 等で取りまとめられており, これらは国際的にも広く 知られている。筆者の受入研究者である Dr. François Toutlemonde と Mr. Bruno Godart は JCI のマスコンク リート委員会（委員長：佐藤良一教授）にも参加して $\mathrm{DEF}$ に関する情報を提供しており，最新情報は日本に も発信されている。

上述したガイドライン等は実務でも積極的に活用され ている。先日, 筆者はローヌーアルプ地方にある Pont de Seyssel の調査を見学させていただいた（写真-3）。Pont de Seyssel は1987 年に建設された橋梁で, 現在 ASR と DEF の複合で主塔および橋脚の一部でひび割れが発生 している。橋梁の劣化はASR が主要因で，DEFによる 膨張は現時点では限定的とのことであった。モニタリン グの結果によれば膨張量は $0.2 \%$ 程度であるが, コアの 調査結果によればマスコン部では今後 DEFによる膨張 の進行が懸念されている。当日の調査では，ひび割れ深 さの確認や鉄筋の健全性調査などがなされた。その他,

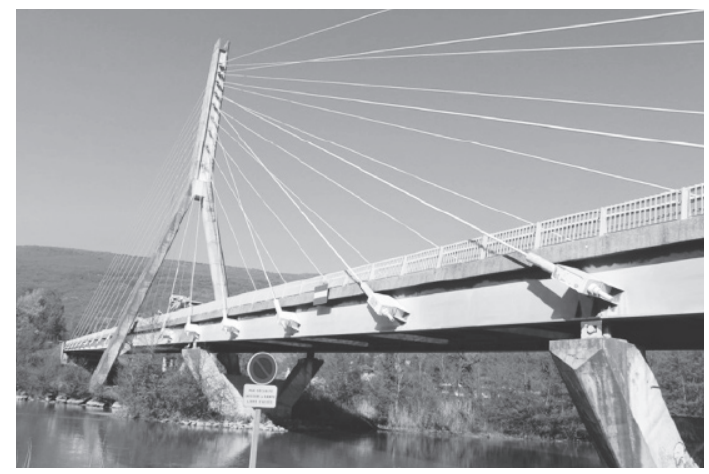

写真-3 Pont de Seyssel（主塔と橋脚が ASR で劣化）
IFSTTAR が開発中のソフトウェアを用いて数值解析を 行い, 今後の変形予測を行った上でモニタリングを行う ことなどが計画されている。このような現場と研究所の 連携は非常に重要で勉強になった。

\section{フランス生活}

日常会話のほとんどはフランス語であり，日常のコ ミュニケーションは難しい。渡航前はフランス語を一切 勉強していなかったため, 生活基盤を整えるのには相当 苦労した。現在はフランス語講座を週 1 回受講している が，習得するには程遠い。フランス語の文法等で分から ないことがあり，その理由を同僚に尋ねると，度々「美 しいから」という回答が返ってくる。フランス語を習得 するには，まずフランスの美的感覚を勉強する必要があ りそうだ。

研究室間も皆仲がよく, 幾つかの研究室が集まってラ ンチを取ることもあり, 雲囲気は大学に近いかもしれな い。朝にカフェで 30 分, 昼食+カフェで 1 時間, とお しゃべり好きなフランス人とゆっくりと時間を共有する ことは日本ではなかなかできないことでもあり，新鮮に 感じた。このようなフランス時間に困ることもたまにあ るが, 親日家も多く, 様々な場面で友人達に助けていた だいている。

1 月にはシャルリー・エブド襲撃事件もあり, フラン スの様々な面を身近に見る機会があった。フランスは他 にも多くの民族問題を抱えている。前述のPont de Seysselの見学の際には, サヴォワ県の一部の住民が独 立を主張しており，舗装に写真-4のような落書きも見 られた。研究所内にも様々な地域・国の研究者がいるた め，関連の話になると議論が白熱することも多々ある。 このような様々な価值観に触れることができることは良 い機会だと思う。（議論が始まるとフランス語になるの で，ほぼ理解できないが・・・）

フランスに渡航して約 8 カ月経過し, 残り $2 / 3$ となっ た。このような留学の機会を与えていただいた多くの 方々に感謝し, 州国後に少しでも貢献できるよう研鑽し たい。

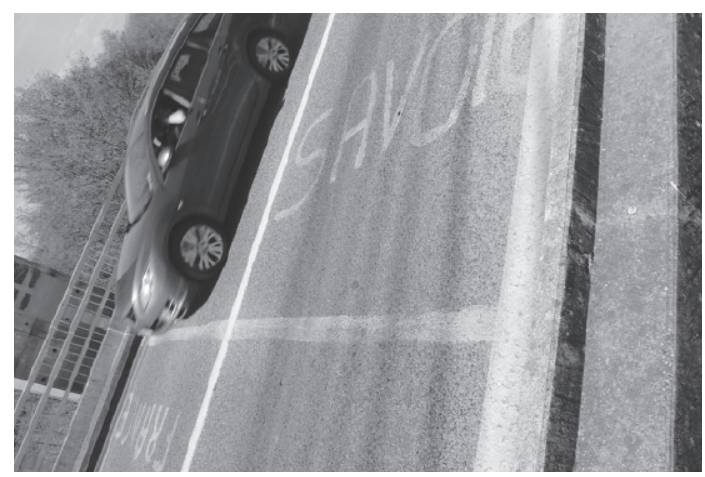

写真-4 舗装の落書き（白線より左がフランス, 右がサヴォワ と書いて独立を主張) 